\title{
Coxib medications to be handled with care
}

Published at www.cmaj.ca on Dec. 22, 2004.

Reasons for posting: On December 17, 2004, Pfizer and the US National Cancer Institute announced that they have stopped administering Celebrex (celecoxib), a cyclooxygenase-2 (COX-2) inhibitor, in an ongoing clinical trial investigating its use to prevent colon polyps because of an increased risk of cardiovascular events. Merck's rofecoxib (Vioxx), another COX-2 inhibitor, was withdrawn from the market worldwide in September 2004 because of an increased risk of myocardial infarction and stroke. In Canada, celecoxib has been approved in the treatment of rheumatoid arthritis, osteoarthritis and familial adenomatous polyposis. ${ }^{1}$ The risk of myocardial infarction and cerebrovascular accident has been found to be increased in pa-

\section{Canadian Adverse}

Reaction Newsletter

Bulletin canadien des effets indésirables

To receive the Newsletter and health product Advisories by email, join Health Canada's Health_Prod_Info mailing list.

Go to www.hc-sc.gc.calhpfb-dgpsa ltpd-dpt/subscribe_e.html.

Inscrivez-vous à la liste

Info_Prod_Santé de Santé Canada pour recevoir par courriel le Bulletin et les Avis au sujet des produits de santé. Rendez-vous à l'adresse www.hc-sc.gc.calhpfb-dgpsaltpd-dpt Isubscribe_f.html.

Report adverse reactions toll free to Health Canada • Signaler sans frais des effets indésirables à Santé Canada

Tel./Tél. : 866 234-2345

Fax/Téléc. : 866 678-6789

Email/Courriel: cadrmp@hc-sc.gc.ca Health Santé
Canada Canada tients taking $400-800 \mathrm{mg} /$ day of celecoxib, but not in patients taking lower doses. The future use and availability of the drug is uncertain. ${ }^{2}$ At the time of writing, detailed study results have not been released.

Given that 2 of the COX-2 inhibitors have shown adverse cardiovascular events, will others eventually reveal the same problems? Some physicians have recommended against prescribing another COX-2 inhibitor, valdecoxib (Bextra), until "there are better safety data." ${ }^{3}$ It is known that valdecoxib can cause serious skin side effects, and it increases the risk of heart attack 3 -fold in patients after coronary-artery bypass grafting.

COX-2 inhibitors, which were originally studied on a theoretical basis for possible beneficial effects in cancer prevention, prompted other research directed at their antiinflammatory effects in joints without causing the gastrointestinal bleeding associated with nonselective NSAIDs. ${ }^{4}$ The indication for COX-2 inhibitors is very narrow: short-term pain control in elderly patients at high risk of gastrointestinal bleeding in whom NSAIDs might be relatively contraindicated. However, they soon became widely and indiscriminately used in place of NSAIDs even though preliminary trial evidence with rofecoxib showed excess, although not statistically significant, cardiovascular and neurovascular events when compared with nonselective NSAIDs.

The drug: Celecoxib belongs to the class of NSAIDs that selectively inhibit COX-2, an enzyme that is produced primarily in response to tissue damage and that is involved in inflammatory responses to injury. ${ }^{5}$ COX-2 was discovered accidentally during genetic cancer re- search. The logic of using COX-2 inhibitors as a replacement for NSAIDs was that blocking the enzyme would reduce the risk of gastrointestinal ulcers and bleeding.

What to do: Evidence speaks against wide and long-term use of COX-2 inhibitors if serious side effects are to be avoided. ${ }^{6}$ Some patients, particularly those at high risk for gastrointestinal bleeding, may present with risk-benefit ratios that will warrant prescription of COX-2 inhibitors. If the drugs are prescribed, patients should be informed that the risk ratio for cardiovascular events is between 2.5 and 3.5 in patients taking very high doses (400-800 mg/day). It is recommended that the lowest effective dose be used if no alternative therapy can be found. The absolute and relative risks for myocardial infarction at lower doses are not known.

\section{Aleksandra Mišak}

Editorial Fellow, CMAJ

\section{References}

1. Health Canada. Conditional approval of CELEBREX* in familial adenomatous polyposis (FAP): fact sheet. May 2004. Available: www.hc-sc.gc.ca/hpfbdgpsa/tpd-dpt/celebrexfactsheet_e.html (accessed 2004 Dec 20).

2. Berenson A. Pfizer to halt advertising of celebrex to consumers. New York Times 2004 Dec 20. Available: www.nytimes.com/2004/12/20/business /20drug.html (accessed 2004 Dec 20).

3. Ray WA, Griffin MR, Stein CM. Cardiovascular toxicity of valdecoxib [letter]. N Engl 7 Med 2004;351:2767.

4. Meier B. Medicine fueled by marketing intensified trouble for pain pills. New York Times 2004 Dec 19. Available: www.nytimes.com/2004/12/19 /business/19drug.html (accessed 2004 Dec 20).

5. Wright JM. The double-edged sword of COX-2 selective NSAIDs. CMAJ 2002;167(10):1131-7.

6. Wooltorton E. What's all the fuss? Safety concerns about COX-2 inhibitors rofecoxib (Vioxx) and celecoxib (Celebrex). CMA7 2002;166 (13):1692-3

7. Food and Drug Administration. FDA statement on the halting of a clinical trial of the Cox-2 inhibitor Celebrex. 2004 Dec 17. Available: www.fda.gov /bbs/topics/news/2004/new01144.html (accessed 2004 Dec 21). 